\title{
A Systematic Review of Randomized Controlled Trials in Anterior Cruciate Ligament Reconstruction: Standard Techniques Are Comparable (299 Trials With 25,816 Patients)
}

\author{
Hosam E. Matar, M.Sc. (Res.) F.R.C.S. (Tr. \& Orth.), Simon R. Platt, F.R.C.S. (Tr. \& Orth.), \\ Benjamin V. Bloch, F.R.C.S. (Tr. \& Orth.), Peter J. James, F.R.C.S. (Tr. \& Orth.), and \\ Hugh U. Cameron, F.R.C.S.C.
}

\begin{abstract}
Purpose: To provide an overview of all published randomized controlled trials (RCTs) in anterior cruciate ligament reconstruction (ACLR) summarizing the available evidence. Methods: Following PRISMA (Preferred Reporting Items for Systematic Reviews and Meta-Analyses) guidelines, we searched the Cochrane FIGCentral Register of Controlled Trials, Ovid MEDLINE, and Embase for RCTs of ACLR from their inception to August 26, 2020. Outcome measure was whether RCTs reported statistically significant findings. RCTs were then classified according to their intervention groups in a narrative synthesis of the evidence. Results: In total, 299 RCTs met the inclusion criteria and were included with a total number of 25,186 patients. Only 30 RCTs $(10 \%)$ reported significant differences between the intervention and the control groups. These included 101 RCTs on grafts, 20 RCTs on tunnel placements, 48 RCTs on graft fixation, 42 RCTs on singlebundle compared with double-bundle reconstructions, 11 RCTs on additional procedures, 11 RCTs on graft tensioning, 5 RCTs on timing of surgery, 25 RCTs on technical variations from standard techniques, 6 RCTs on ACL repair, 5 RCTs on navigation, 16 RCTs on perioperative management, and 9 RCTs on other aspects of ACLR. Only 14 RCTs $(4.7 \%)$ reported outcomes beyond 10 years with greater allograft failures compared with autografts, high incidence of osteoarthritic changes in reconstructed knees (22\%-100\%), with no significant differences in outcomes between bioabsorbable or metal screws for graft fixation, patellar versus hamstrings or single- versus double-bundle reconstructions. Conclusions: The evidence indicates that a standard arthroscopic single- or double-bundle ACLR with hamstrings/patella autografts, transportal technique, and fixation techniques familiar to the surgeon leads to comparable results. This evidence offers surgeons the flexibility to use standard and cost-effective techniques and achieve comparable outcomes. Level of Evidence: Level II; systematic review of Level I-II randomized controlled trials.
\end{abstract}

From Nottingham Elective Orthopedic Services, Nottingham University Hospitals NHS Trust, Nottingham, United Kingdom (H.E.M., B.V.B., P.J.J.); Department of Orthopedic Surgery, Gold Coast University Hospital, Southport, Australia (S.R.P.); and Holland Orthopedic $\theta$ Arthritic Centre, Sunnybrook Health Sciences, University of Toronto, Toronto, Canada (H.U.C.).

The authors report that they have no conflicts of interest in the authorship and publication of this article. Full ICMJE author disclosure forms are available for this article online, as supplementary material.

Received December 20, 2020; accepted March 24, 2021.

Address correspondence to Hosam E. Matar, M.Sc. (Res.), F.R.C.S. (Tr. $\theta$ Orth.), Nottingham Elective Orthopedic Services, Nottingham University Hospitals NHS Trust, Nottingham, NG5 1PB, United Kingdom. E-mail: hematar@doctors.org.uk

Crown Copyright (c) 2021 Published by Elsevier Inc. on behalf of the Arthroscopy Association of North America. This is an open access article under the CC BY-NC-ND license (http://creativecommons.org/licenses/by-nc-nd/4.0/). 2666-061X/202010

https://doi.org/10.1016/j.asmr.2021.03.017
$\mathbf{T}$ he anterior cruciate ligament (ACL) is the most commonly injured ligament in the knee, with $\sim 200,000$ anterior cruciate ligament reconstructions (ACLR) per year in the United States alone and an estimated 400,000 ACLRs per year worldwide. ${ }^{1-3}$ There is a substantial variation in ACLR surgery worldwide. Prentice et al. $^{4}$ reported on a combined cohort of 101,125 ACLRs across 6 national, regional, and hospital-based registries (Denmark, Luxembourg, Norway, Sweden, UK, and the U.S.-based Kaiser Permanente registry). European countries mostly used autografts whereas allografts were more commonly used in the United States. Interference screw fixation was the most frequent femoral fixation technique in Luxembourg and the United States, whereas suspensory fixation was more frequently used in other 
countries. Interference screw was the most frequent tibial fixation type in all 6 cohorts, with overall 3-year cumulative revision ACLR rate of $2.8 \%$ to $3.7 \%{ }^{4}$

The modern intra-articular ACLR is largely based on the Hey Groves' operation, which he described in 1917 using a strip of fascia lata passed through a tibial tunnel. ${ }^{5,6}$ Almost a century later, the debate continues in the literature on the timing of surgery, the best choice of graft to use, and single- versus double-bundle reconstruction and tunnel placements, to name but a few. ACLR is one of the most-studied procedures in sports medicine. with more than 22,000 publications on PubMed and more than 1,800 published in 2019 alone. In recognition of this challenge, the Panther Symposium ACL Injury Clinical Outcomes Consensus Group has recently published their consensus paper providing practical guidelines on preferred tools for reliable and valid assessment of outcomes after ACL treatment. ${ }^{7}$

High-quality randomized controlled trials (RCTs) provide strong evidence for the efficacy of health care interventions and help to inform evidence-based practice. ${ }^{8,9}$ This is especially true of RCTs, which show a statistically significant difference in the results of 2 treatments, or the absence of a significant difference but a narrow confidence interval indicating a positive effect of a treatment. ${ }^{10,11}$

Numerous systematic reviews have been published looking at specific aspects of ACLR. ${ }^{12-14}$ Notably, in their Level IV evidence systematic review of systematic reviews on ACLR, Anderson et al. ${ }^{15}$ provided a summary of 240 studies in an attempt to synthesize the literature, whereas Kay et al. ${ }^{16}$ focused on quality of reporting RCTs in ACLR and found that reporting of a methodologically sound randomization process and prospective calculation of sample size have significantly improved in recent years. The first of these 2 examples included all reviews of different study designs and the second focused on quality of reporting RCTs rather than the contents or results of those trials. The purpose of this systematic review is to provide an overview of all published RCTs in ACLR summarizing the available evidence. We hypothesized that the majority of RCTs in ACLR would find no significant differences.

\section{Methods}

Following PRISMA (Preferred Reporting Items for Systematic Reviews and Meta-Analyses) guidelines, ${ }^{17}$ we searched the Cochrane Central Register of Controlled Trials (CENTRAL, 2020, Issue 2), Ovid MEDLINE (including Epub Ahead of Print, In-Process 8 Other Non-Indexed Citations, Ovid MEDLINE Daily, Ovid MEDLINE and Versions) (1946 to August 26, 2020), and Embase (1980 toAugust 26,2020$)$. We limited our searches to the English-language literature. In MEDLINE, we combined the subject-specific search strategy with the sensitivity maximizing version of the
Cochrane Highly Sensitive Search Strategy for identifying randomized trials. ${ }^{18}$

The following search strategy was used [ $(\mathrm{rct}$ OR randomised OR randomized OR "clinical trial" OR blinded OR "controlled trial").ti,ab* "anterior cruciate ligament reconstruction"/ OR *"bone-patellar tendonbone grafting"/ ("anterior cruciate ligament reconstruction" OR "anterior cruciate ligament reconstructive surger*" OR "ACL reconstruction" OR "ACL reconstructive surger*").ti,ab* OR *"anterior cruciate ligament repair" $/$.

We examined the titles and abstracts of articles identified in the search as potentially relevant trials. We obtained the full texts of trials that fulfilled our inclusion criteria (i.e., randomized controlled trials of ACLR; Levels I-II) and those that were unclear from perusal of the abstracts. We excluded nonrandomized trials, trials on revision ACLR, biomechanical or cadaver studies, systematic reviews and meta-analyses. Multiple publications of the same trial were counted as l RCT and counted if included new outcomes or longer follow-up. The reference lists of included studies were also searched. Trials that met our inclusion criteria were assessed by 2 authors (H.E.M., S.R.P.) using a binary outcome measure of whether they reported statistically significant findings. Any disagreements were resolved by discussions and consulting with a third author (B.V.B.).

These were then classified according to intervention groups in a narrative review summarizing the evidence. Results were expressed descriptively in numbers and percentages. SPSS 16.0 software (SPSS Inc., Chicago, Illinois, IL) was used for descriptive statistical analysis.

\section{Results}

The electronic searches produced 4,102 records, with a further 11 records identified from reference lists of some included studies. After removing duplicates and screening abstracts 1,405 studies were assessed for eligibility and 299 RCTs (309 publications) met the inclusion criteria and were included (Fig 1).

The total number of patients in those 299 RCTs was 25,186 patients. Only 30 RCTs $(10 \%)$ reported significant differences between the intervention and the control groups (Table 1). The number of RCTs published per year has increased steadily since the early 1990s to an annual average of 25 RCTs over the last few years (Fig 2).

\section{Graft Choice}

In total, 101 RCTs evaluated grafts in ACLR with a total of 9,346 patients; 45 RCTs compared hamstrings autografts with bone-patellar tendon-bone (BPTB), 28 RCTs evaluated allografts (compared with autografts or other allografts), 12 RCTs compared different hamstrings techniques (including different number of 
strands, preserved tibial attachments, etc.), 6 RCTs evaluated quadriceps grafts, 3 evaluated other autografts such as iliotibial band or anterior half of peroneus longus, and finally 7 RCTs evaluated synthetic grafts (Table 1).

Only 8 RCTs $(7.9 \%)$ reported significant differences (Table 2). Tian et al. ${ }^{19}$ compared irradiated versus nonirradiated allografts at 5.7 years' follow-up and reported better stability and less radiographic progression of arthritis with nonirradiated allografts, although there were no significant differences in functional scores. Niu et al. $^{20}$ compared double-layer BPTB with 4-strand hamstrings allografts at 3 years with significantly lower rate of graft failure and better functional scores with BPTB allografts. Bottoni et al. ${ }^{21}$ compared hamstring autografts with tibialis posterior allografts at 10 years' follow-up and reported a greater failure rate in the allograft group requiring revision reconstruction $(26.5 \%$ vs $8.3 \%)$. Zhao et al. ${ }^{22}$ reported significant differences in stability and functional scores in favor of 8-strand hamstrings compared with 4-strand autografts at 2 years' follow-up. Ferretti et al. ${ }^{23}$ reported better internal rotation strength using their modified technique in preserving the distal insertion of the hamstrings autografts compared with standard harvesting technique. Both Mohtadi et al. ${ }^{24}$ and Zaffagnini et al. ${ }^{25}$ compared BPTB with hamstrings autografts at 5 years' follow-up and reported no significant differences in functional scores. Both studies reported more anterior knee pain with BPTB but more traumatic reinjuries with hamstrings grafts. Finally, in one of the first RCTs in ACLR (1990), Dahlstedt et al. ${ }^{26}$ reported high complications and worse outcomes with Gore-Tex prosthetic ligament reconstruction compared with the Kennedy ligament augmentation device at 3 years' follow-up.

\section{Femoral Tunnel Techniques}

Twenty RCTs with a total of 1,670 patients evaluated portal techniques. Thirteen RCTs compared
Fig 1. PRISMA (Preferred Reporting Items for Systematic Reviews and Meta-Analyses) flow diagram of electronic searches results and included studies. (ACL, anterior cruciate ligament; RCT, randomized controlled trial.)
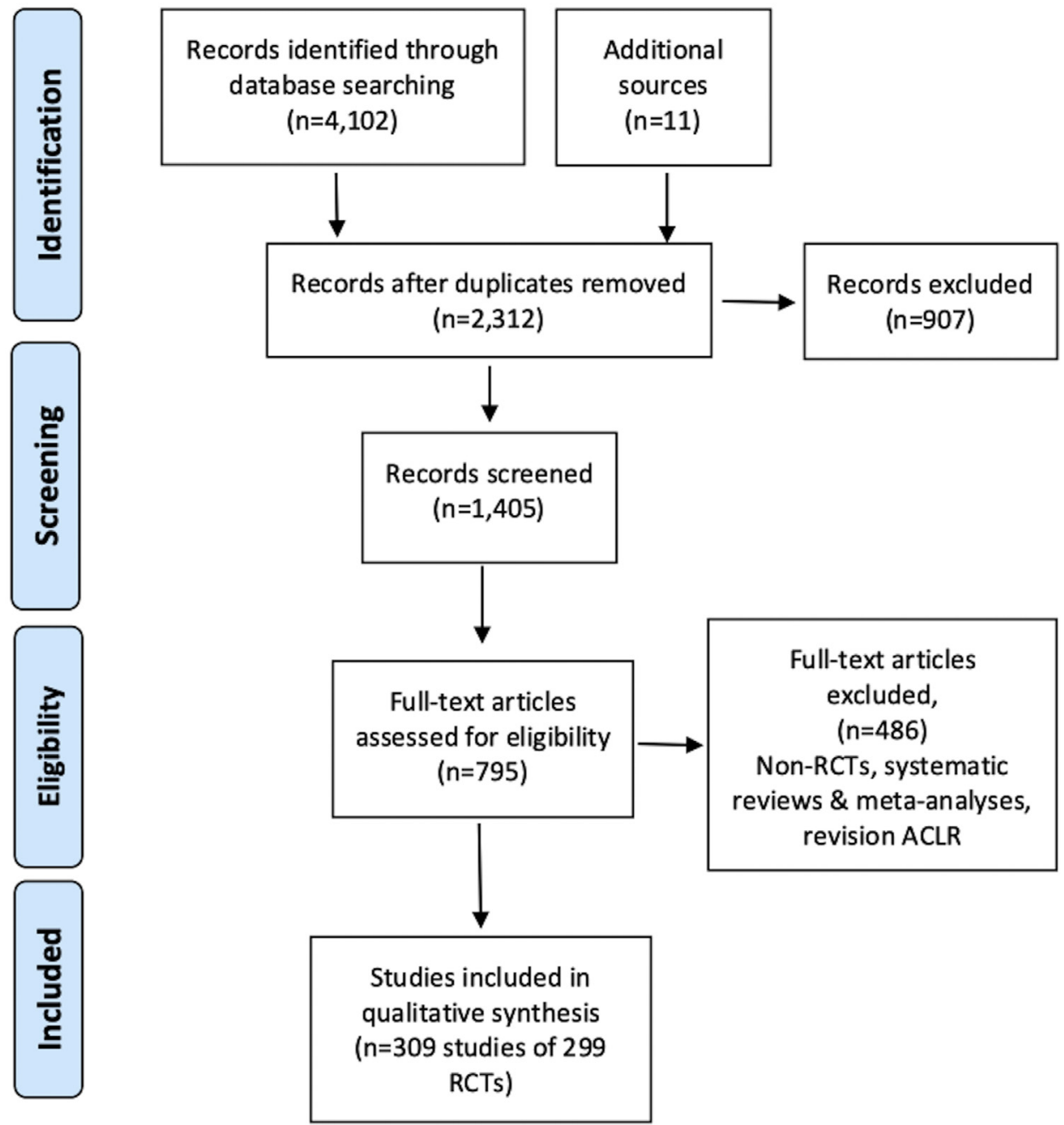
Table 1. Summary of RCTs and Total Number of Patients Included

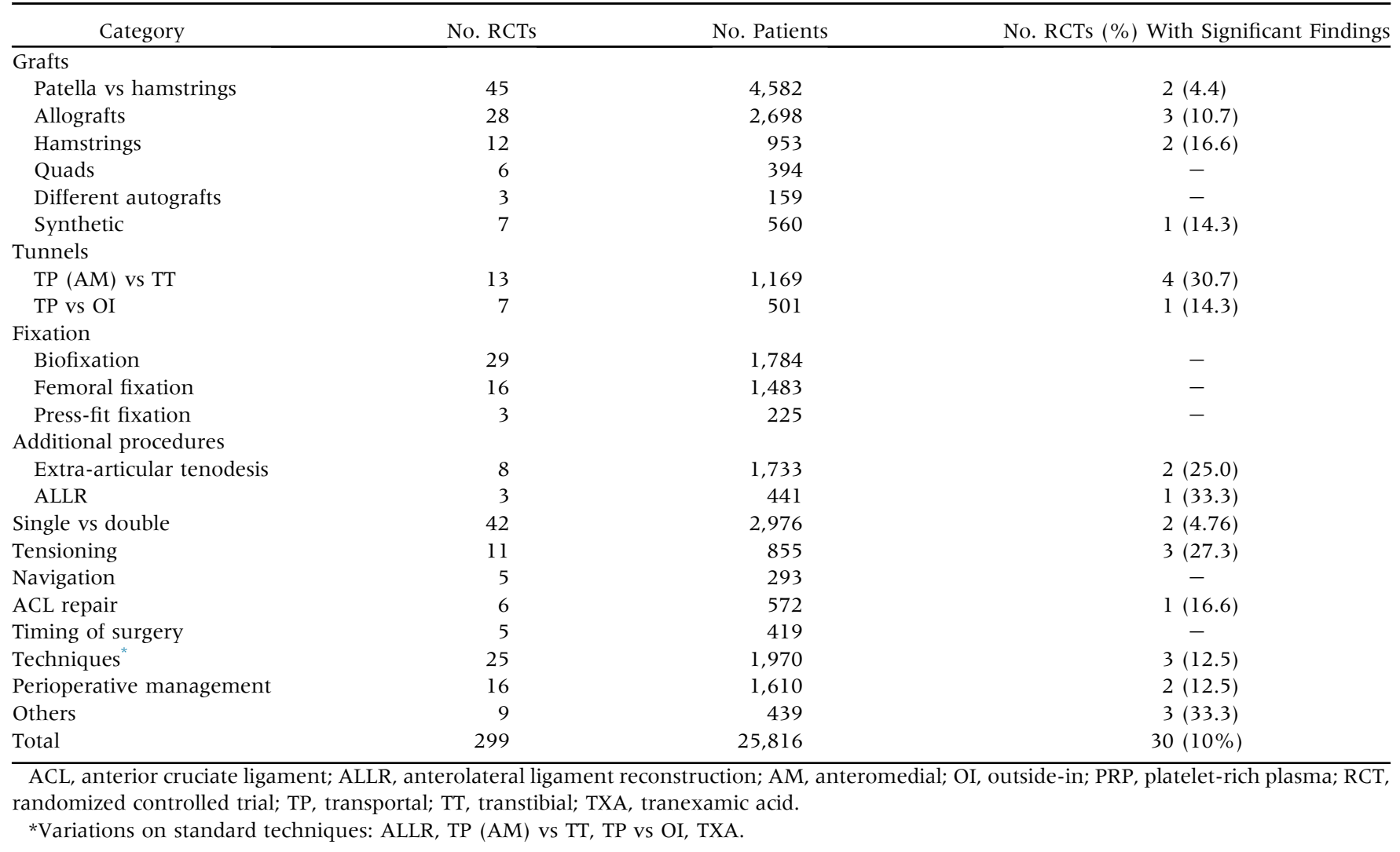

"anteromedial/transportal" versus "transtibial" techniques to prepare the femoral tunnels, and 7 RCTs compared "transportal" versus "outside-in" techniques. Five RCTs reported significant findings. Femoral tunnel positions were compared using computed tomography between transtibial and transportal techniques by
Takeda et al., ${ }^{27}$ Venosa et al., ${ }^{28}$ and Mirzatolooei, ${ }^{29}$ and all reported significant differences with more anatomical positioning achieved by the transportal technique. Similarly, transportal technique showed similar results when compared with outside-in technique by Kim et al. $^{30}$ and Nakamura et al., ${ }^{31}$ who compared the 3
35

30

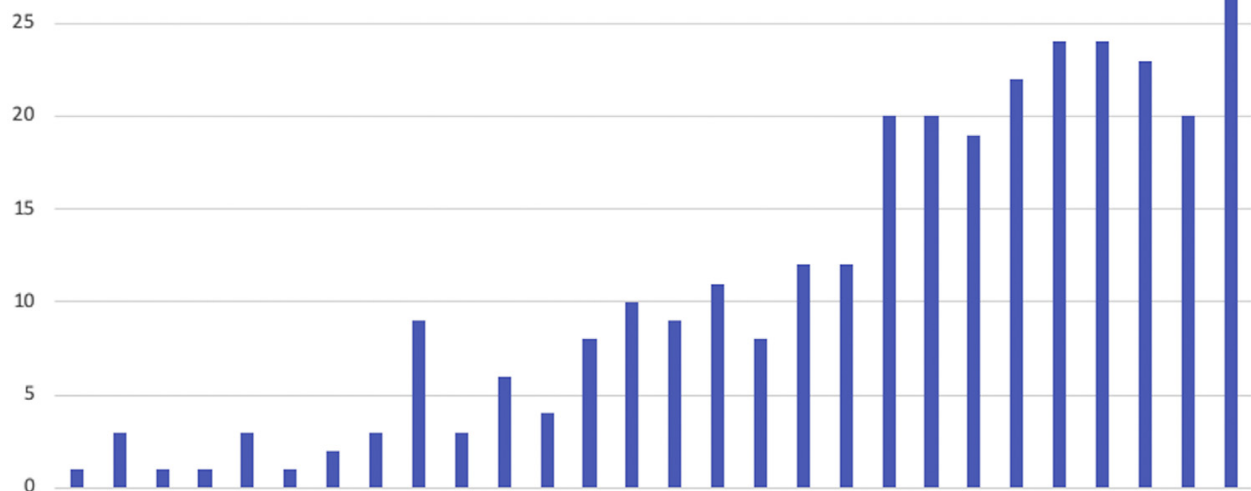

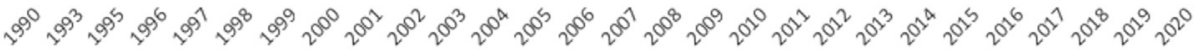

Fig 2. Number of RCTs per year of publication. (RCT, randomized controlled trial.) 
Table 2. Summary of Grafts RCTs With Significant Findings

\begin{tabular}{|c|c|c|c|c|c|}
\hline RCT & $\begin{array}{c}\text { Level of } \\
\text { Evidence }\end{array}$ & Subgroup & Interventions & Outcome Measures & Results \\
\hline $\begin{array}{l}\text { Tian et al., } \\
2017^{19}\end{array}$ & I & Allograft & $\begin{array}{l}\text { Irradiated vs nonirradiated } \\
\text { hamstrings allograft } \\
\text { double bundle at } 5.7 \\
\text { years' FU }(\mathrm{n}=83 / 112)\end{array}$ & $\begin{array}{l}\text { Lachman test, pivot shift } \\
\text { test, KT-2000 } \\
\text { arthrometer, IKDC, } \\
\text { functional, subjective } \\
\text { evaluations, activity } \\
\text { level testing, and } \\
\text { radiologic assessment. }\end{array}$ & $\begin{array}{l}\text { Significant increase in laxity and } \\
\text { arthritic progression found in } \\
\text { irradiated grafts; KT-2000: } \\
86.4 \% \text { Non-ir-Allo vs } 35.9 \% \text { Ir- } \\
\text { Allo had a side-to-side } \\
\text { difference of }<3 \mathrm{~mm}(P<.05) \text {. } \\
\text { Arthritic progression: } 30.8 \% \text { Ir- } \\
\text { Allo group vs } 11.4 \% \text { Non-ir- } \\
\text { Allo group }(P<.05) \text {. } \\
\text { No significant differences in } \\
\text { activity level or functional } \\
\text { scores. }\end{array}$ \\
\hline Niu et al., $2016^{20}$ & II & Allograft & $\begin{array}{l}\text { Double-layer BPTB } \\
\text { allografts vs } 4 \text {-strand } \\
\text { hamstrings allograft at } 3 \\
\text { years' FU }(n=101)\end{array}$ & $\begin{array}{l}\text { Graft failure, KT-1000 } \\
\text { arthrometer, Lachman } \\
\text { tests, pivot-shift tests, } \\
\text { IKDC, and Lysholm } \\
\text { scores. }\end{array}$ & $\begin{array}{l}\text { Graft failure: } 2(4 \%) \text { BPTB vs } 9 \\
(17.6 \%) 4-S H(P=.028) . \\
\text { Significantly better Lachman } \\
\text { test, IKDC knee score, and } \\
\text { Lysholm score in favor of BPTB } \\
(P<.05) \text { although below the } \\
\text { threshold for clinical } \\
\text { significance. }\end{array}$ \\
\hline $\begin{array}{c}\text { Bottoni et al., } \\
2015^{21}\end{array}$ & I & Allograft & $\begin{array}{l}\text { Hamstring autograft vs } \\
\text { tibialis posterior allograft } \\
\text { at minimum } 10 \text { years' } \\
\text { FU }(\mathrm{n}=96 / 99)\end{array}$ & $\begin{array}{l}\text { Graft failure, subjective } \\
\text { knee stability, and } \\
\text { functional status SANE, } \\
\text { Tegner, and IKDC scores. }\end{array}$ & $\begin{array}{l}4(8.3 \%) \text { autograft vs } 13(26.5 \%) \\
\text { allograft failures that required } \\
\text { revision reconstruction. In the } \\
\text { remaining patients whose graft } \\
\text { was intact, there was no } \\
\text { difference in functional scores. }\end{array}$ \\
\hline $\begin{array}{l}\text { Zhao et al., } \\
2007^{22}\end{array}$ & II & Hamstrings & $\begin{array}{l}\text { 4- vs } 8 \text {-strands hamstrings } \\
\text { double bundle at } \\
\text { minimum } 2 \text { years' FU } \\
(\mathrm{n}=68 / 76)\end{array}$ & $\begin{array}{l}\text { KT-1000 arthrometer, } \\
\text { IKCD, and Lysholm } \\
\text { scores. }\end{array}$ & $\begin{array}{l}\text { 8-SHG had significantly better } \\
\text { results with: mean side-to-side } \\
\text { difference in anterior knee } \\
\text { laxity: } 1.3 \text { vs } 2.8 \mathrm{~mm}(P= \\
\text {.0003). } \\
\text { IKDC subjective: } 96.3 \text { vs } 86.4 \\
(P=.0007) \\
\text { Lysholm score: } 96.5 \text { vs } 89.6 \\
(P=.0006)\end{array}$ \\
\hline $\begin{array}{l}\text { Mohtadi et al., } \\
2019^{24}\end{array}$ & I & $\begin{array}{l}\text { Patella vs } \\
\text { hamstrings }\end{array}$ & $\begin{array}{l}\text { Patellar tendon, single- } \\
\text { bundle } 4 \text {-stranded } \\
\text { hamstrings, or double- } \\
\text { bundle hamstrings } \\
\text { reconstruction at } 5 \text { years' } \\
\text { FU }(\mathrm{n}=315 / 330) \text {. }\end{array}$ & $\begin{array}{l}\text { ACL-QoL, IKDC, kneeling } \\
\text { pain, Tegner activity } \\
\text { scale, Cincinnati } \\
\text { Occupational Rating } \\
\text { Scale, re-ruptures, } \\
\text { partial traumatic tears, } \\
\text { total traumatic } \\
\text { reinjuries, and } \\
\text { atraumatic graft failures. }\end{array}$ & $\begin{array}{l}\text { No difference in primary outcome } \\
\text { ACL-QOL scores between } \\
\text { groups }(P=.548) \text {. No } \\
\text { differences in IKDC, ROM, } \\
\text { Cincinnati or Tegner scores. } \\
\text { Kneeling pain: } 10 \% \text { vs } 4 \% \text { vs } \\
2 \%(P=.029) \text {. } \\
\text { Significantly more patients in } \\
\text { the hamstring and double- } \\
\text { bundle groups experienced } \\
\text { traumatic graft reinjury } \\
\text { compared with the patellar } \\
\text { tendon group. } \\
\text { Combined traumatic reinjuries: } \\
4 \text { vs } 16 \text { vs } 17(P=.01)\end{array}$ \\
\hline
\end{tabular}


Table 2. Continued

\begin{tabular}{|c|c|c|c|c|c|}
\hline RCT & $\begin{array}{l}\text { Level of } \\
\text { Evidence }\end{array}$ & Subgroup & Interventions & Outcome Measures & Results \\
\hline $\begin{array}{l}\text { Zaffagnini et al., } \\
2006^{25}\end{array}$ & II & $\begin{array}{l}\text { Patella vs } \\
\text { hamstrings }\end{array}$ & $\begin{array}{l}\text { BPTB, 4-strand hamstrings } \\
\text { or single hamstrings with } \\
\text { extra-articular plasty at } 5 \\
\text { years' FU }(\mathrm{n}=75)\end{array}$ & $\begin{array}{l}\text { IKDC, IKDC subjective, } \\
\text { Tegner, muscle } \\
\text { circumference, anterior } \\
\text { knee pain, kneeling pain }\end{array}$ & $\begin{array}{l}\text { Anterior knee pain: } 36 \% \text { vs } 12 \% \\
\text { vs } 8 \%(P=.03) \\
\text { Kneeling pain: } 72 \% \text { vs } 44 \% \text { vs } \\
12 \%(P=.0001) \\
\text { IKDC subjective: } 82 \text { vs } 76 \text { vs } 89 \\
(P=.04) \\
\text { No significant differences in } \\
\text { functional scores. }\end{array}$ \\
\hline $\begin{array}{l}\text { Dahlstedt et al., } \\
1990^{26}\end{array}$ & II & Synthetic graft & $\begin{array}{l}\text { Gore-Tex prosthetic } \\
\text { ligament vs Kennedy } \\
\text { ligament augmentation } \\
\text { device at } 3 \text { years' FU } \\
(\mathrm{n}=41)\end{array}$ & $\begin{array}{l}\text { Lysholm scores, activity } \\
\text { scores, and arthrometry }\end{array}$ & $\begin{array}{l}\text { Better outcomes with } \\
\text { augmentation device and more } \\
\text { complication with Gore-Tex } \\
\text { group. }\end{array}$ \\
\hline
\end{tabular}

ACL-QoL, anterior cruciate ligament quality of life; BPTB, bone-patella tendon-bone; FU, follow-up; IKDC, International Knee Documentation Committee; MRI, magnetic resonance imaging; RCT, randomized controlled trial; ROM, range of motion.

techniques (transtibial, transportal and outside-in) (Table 3).

\section{Graft Fixation}

Forty-eight RCTs with a total of 3,492 patients compared different methods of graft fixation (Appendix Table 1, available at www.arthroscopyjournal.org). None have reported significant differences. A total of 29 RCTs evaluated bioabsorbable fixation techniques, particularly bioabsorbable screws versus metal screws, and 16 RCTs compared different techniques of femoral graft fixation including screws versus suspensory button or screws versus cross pin fixation. The remaining 3 RCTs compared the press-fit fixation technique with conventional or interference screw technique with no significant differences reported.

\section{Additional Procedures}

Eleven RCTs compared the added value of additional procedures with the conventional ACLR including 8 RCTs with 1,733 patients that evaluated lateral extraarticular tenodesis. Two of these RCTs (25\%) reported significant differences. In their STABILITY trial, Getgood et al. ${ }^{32}$ randomized 618 young patients $(<25$ years) to single-bundle ACLR with or without lateral extra-articular tenodesis and reported a statistically significant reduction in graft rupture and persistent rotatory laxity at 2 years after surgery, although there were no statistically significant differences in patientreported or functional outcome scores. Porter and Shadbolt ${ }^{33}$ compared a modified iliotibial band tenodesis with standard ACLR at 2 years in 55 patients. They also reported reduced graft failure and better scores on some reported outcome measures; Knee injury and Osteoarthritis Outcome Score subscale of sport/recreation, Lysholm score, and Tegner activity scale. It is worth noting, however, that participants in both trials were at high risk of failure.
A further 3 RCTs compared the combined anterolateral ligament reconstruction with ACLR compared with ACLR alone, with 1 trial reporting significant differences. Hamido et al. ${ }^{34}$ randomized 107 male athletes and reported reduced instrumented knee laxity and a lower rate of graft failure with the added anterolateral ligament reconstruction at 60 months' follow-up.

\section{Single- Versus Double-Bundle Reconstruction}

A total of 42 RCTs compared single- versus doublebundle reconstruction with a total of 2,976 patients (Appendix Table 1, available at www. arthroscopyjournal.org); only 2 RCTs $(4.76 \%)$ reported significant differences. Siebold et al. ${ }^{35}$ reported significantly greater objective but not subjective International Knee Documentation Committee (IKDC) scores as well as improved rotational stability with double-bundle reconstructions in 70 patients at 19 months' follow-up. There were no differences in other outcome measures (Cincinnati knee score, Lysholm score, and subjective IKDC 2000).

Zaffagnini et al. ${ }^{36}$ also reported on their 79 patients at 8-10 years' follow-up. They showed no significant differences in subjective or objective IKDC scores, although the double-bundle group showed significantly greater Tegner level, passive range of motion recovery, faster sport resumption, lower glide pivot-shift, and lower reintervention rates. Their radiographic evaluation also showed significant lower objective degenerative changes in double-bundle group at final follow-up.

\section{Graft Tensioning}

Eleven RCTs with 855 patients compared different tensioning forces or techniques to apply the required tension on the grafts with $3(27.3 \%)$ RCTs reporting significant differences. Yasuda et al. ${ }^{37}$ compared sideto-side knee laxity at 2 years with initial graft tension at $20 \mathrm{~N}, 40 \mathrm{~N}$, or $80 \mathrm{~N}$ in 70 patients and reported that 
Table 3. Summary of Femoral Tunnel Techniques RCTs With Significant Findings

\begin{tabular}{|c|c|c|c|c|c|}
\hline RCT & $\begin{array}{l}\text { Level of } \\
\text { Evidence }\end{array}$ & Subgroup & Interventions & Outcome Measures & Results \\
\hline Takeda et al., $2013^{27}$ & II & TP vs TT & $\begin{array}{l}\text { Anteromedial vs Transtibial } \\
\text { portals double-bundle } \\
\text { hamstrings }(\mathrm{n}=50)\end{array}$ & $\begin{array}{l}\text { Volume-rendering CT, 3D- } \\
\text { CT tunnel placements on } \\
\text { 7th postoperative day. }\end{array}$ & $\begin{array}{l}\text { With AM technique, } \\
\text { femoral tunnels were } \\
\text { placed significantly } \\
\text { deeper, lower, and closer } \\
\text { to the femoral footprint } \\
\text { and the overall femoral } \\
\text { tunnel length was } \\
\text { significantly shorter. }\end{array}$ \\
\hline Venosa et al., $2017^{28}$ & $\mathrm{I}$ & TP vs TT & $\begin{array}{l}\text { Anteromedial vs Transtibial } \\
\text { portals hamstrings }(\mathrm{n}= \\
\text { 52) }\end{array}$ & $\begin{array}{l}\text { Femoral tunnel positioning } \\
\text { 3D-CT }\end{array}$ & $\begin{array}{l}\text { AM portal technique } \\
\text { provided more } \\
\text { anatomical graft } \\
\text { placement than TT } \\
\text { techniques. }\end{array}$ \\
\hline $\begin{array}{l}\text { Mirzatolooei, } \\
2012^{29}\end{array}$ & II & TP vs TT & $\begin{array}{l}\text { Transportal TransFix } \\
\text { femoral fixation vs } \\
\text { Transtibial using } \\
\text { hamstrings at minimum } \\
18 \text { months' FU }(\mathrm{n}=168 \text { / } \\
223 \text { ) }\end{array}$ & $\begin{array}{l}\text { IKDC, Lysholm, Tegner } \\
\text { scores and rolimeter, } \\
\text { tunnel positioning }\end{array}$ & $\begin{array}{l}\text { Better reported outcomes } \\
\text { for TP group: } \\
\text { Laxity (mean difference } \\
\text { between normal / } \\
\text { affected side): TT } 2.2 \pm \\
1.13 \text { vs TP } 1.73 \pm 0.85 \\
\text { mm }(P=.002) . \\
\text { Mean Lysholm score } \\
81.41 \text { TP vs } 78.32 \text { TT } \\
(P=.037) \text {. } \\
\text { More anatomic tunnel } \\
\text { placement with TP }\end{array}$ \\
\hline Kim et al., $2013^{30}$ & I & TP vs OI & $\begin{array}{l}\text { Transportal vs Outside-in } \\
\text { double bundle }(\mathrm{n}=80)\end{array}$ & $\begin{array}{l}\text { CT analysis of the femoral } \\
\text { tunnel position }\end{array}$ & $\begin{array}{l}\text { TP technique had } \\
\text { significantly more } \\
\text { ellipsoidal AM femoral } \\
\text { tunnel aperture than the } \\
\text { OI technique. }\end{array}$ \\
\hline
\end{tabular}

3D, 3-dimensional; AM, anteromedial; CT, computed tomography; FU, follow-up; IKDC, International Knee Documentation Committee; OI, outside-in; RCT, randomized controlled trial; TP, transportal; TT, transtibial.

$80 \mathrm{~N}$ group reduced laxity the most. Khare et al. ${ }^{38}$ compared manual cyclical loading with the use of a tensioner at 1-year follow-up in 50 patients and reported no difference in laxity but better Lysholm score at short-term follow-up. Finally, DeFroda et al. ${ }^{39}$ also compared low-tension with high-tension (overconstrained by $2 \mathrm{~mm}$ ) in 90 patients and reported on 72 patients at 7 years' follow-up using hamstrings or BPTB autografts. There were no differences in the BPTB group but statistically significant differences were reported favoring the high-tension group when the hamstrings grafts were used.

\section{Navigation}

Five small RCTs with 293 patients compared navigation/computer assisted with conventional techniques with no significant differences reported in clinical outcomes although there was an overall trend toward more accurate tunnel placements on radiographic outcomes (Appendix Table 1, available at www. arthroscopyjournal.org).

\section{ACL Repair Versus Reconstruction}

Six RCTs with 572 patients compared a dynamic intraligamentary stabilization technique or bridgeenhanced repair with one trial reporting significant differences. In their trial, Drogset et al. ${ }^{40}$ reported long-term follow-up at 16 years comparing acute primary repair, acute primary repair augmented with a synthetic ligament-augmentation device, or acute repair augmented with BPTB autograft in 129 out of their original 147 patients. Revision rate at 16 years was $24 \%, 10 \%$, and $2 \%$, respectively. However, comparing the outcomes of those who did not require revision showed no significant differences in Lysholm score or radiographic arthritic changes but significantly 
better knee stability with the BPTB group on Lachman testing.

\section{Timing of Surgery}

Early versus delayed ACLR was compared across 5 RCTs. The main trial in this group is the landmark KANON trial (Knee ACL NON-operative vs operative treatment), which has produced multiple publications at various follow-up points and secondary analyses. Frobell et al. ${ }^{41}$ published the 2-year follow-up of the KANON trial comparing "structured rehabilitation plus early ACL reconstruction" with "structured rehabilitation with the option of later ACLR if needed" in 121 patients. Of 59 patients assigned to rehabilitation plus optional delayed ACLR, 23 underwent delayed ACLR; the other 36 underwent rehabilitation alone. There were no differences in either primary or secondary outcomes at 2 years. At 5 years' follow-up, 30 of 59 patients had ACLR and outcomes remained similar between the 2 groups including radiographic arthritic changes or cost-effectiveness. ${ }^{42,43}$ Interestingly, patients who had early ACLR were found to have significantly greater patellofemoral cartilage loss measured on magnetic resonance imaging at 5 years. ${ }^{44}$

Eriksson et al. ${ }^{45}$ also compared early versus delayed and reported their outcomes at 6 months, 1 year, ${ }^{46}$ and 2 years ${ }^{47}$ and reported no significant differences except for more sick days leave taken by patients in the delayed group. The remining 3 RCTs also reported no significant differences (Table 4). ${ }^{41-51}$

\section{Surgical Techniques}

This is a heterogenous group of trials that evaluated modified or variations on standard surgical techniques. For example, RCTs examine the use of OSTEOSET pellets to fill the tibial defect compared with those left empty, water versus saline irrigation, use of a plasma ablation device versus standard ablation device, or standard versus minimal debridement of the ACL remnant; to name but a few (Appendix Table 1, available at www.arthroscopyjournal.org).

There were 25 RCTs with 1,970 patients; only 3 RCTs $(12 \%)$ reported significant findings. Jepsen et al. ${ }^{52}$ compared femoral graft insertion site between the 1o'clock (high) versus 2-o'clock (low) positions in 60 patients using hamstrings grafts and found no significant differences in laxity or objective IKDC scores. However, they did report a significant difference in the subjective IKDC scores favoring low position group (82.8 vs $70.4 ; P<.002 ; \mathrm{n}=51$ ).

Mutsuzaki et al. ${ }^{53}$ compared calcium phosphatehybridized- versus unhybridized hamstrings autografts in single-bundle ACLR and their effects on the morphological changes to bone tunnels at 1-year followup using 3-dimensional computed tomography images in 73 patients. There were no significant differences on the tibial tunnels, but hybridized grafts significantly reduced femoral tunnel enlargement; there were no differences in clinical outcomes or scores. Finally, Funchal et al., ${ }^{54}$ in a recent RCT, compared the outcomes of patients with an arthroscopic floating meniscus sign at 2 years when treated with or without medial compartment reconstruction surgery in 112 patients. Unsurprisingly, patients with combined injuries had a significantly greater frequency of ACLR failure and worse outcomes when treated with ACLR alone.

\section{Perioperative Management}

Sixteen RCTs with 1,610 patients were identified including 2 RCTs on analgesia, 6 RCTs on the use of platelet-rich-plasma (PRP), 4 RCTs on tourniquet use, 3 RCTs on the use of tranexamic acid, and I RCT on the use of human growth hormone (Appendix Table 1, available at www.arthroscopyjournal.org). Only 2 RCTs $(12.5 \%)$ reported significant findings; Vogrin et al. ${ }^{55}$ compared the effects of platelet gel produced from autologous PRP and applied locally on the grafts during ACLR using MRI at 4-6 weeks to measure revascularization in the osteoligamentous interface zone in bone tunnels and in the intra-articular part of the graft. They reported significantly greater level of vascularization with PRP $(0.33 \pm 0.09$ vs $0.16 \pm 0.09, P<.001 ; \mathrm{n}=50)$ in the tunnels but no difference on the intra-articular graft. Reda et al. ${ }^{56}$ compared the use of tourniquet versus no tourniquet during ACLR in 84 patients. Only 58 of 84 patients were included at 2 weeks' follow-up and reported significantly more pain and hemarthrosis in the tourniquet group.

\section{Others}

In this group there were 9 RCTs with 439 patients (Appendix Table 1, available at WwW. arthroscopyjournal.org). These included 3 RCTs on different rehabilitation regimes with none reporting significant differences. A further 3 RCTs compared open versus arthroscopic ACLR; one trial reported statistically significant differences favoring arthroscopic ACLR at 6 months. ${ }^{57}$ Two RCTs compared outpatients versus inpatients ACLR with one trial reported better patients' satisfaction at 1 -week with outpatient procedures. ${ }^{58}$ Finally, in their interesting long-term results, Meunier et al. $^{59}$ reported the outcomes of operative (primary repair augmented or nonaugmented) versus nonoperative management of ACL ruptures in 100 patients at 15 years. Subjectively, there were no differences in activity level or Knee injury and Osteoarthritis Outcome Score score but with a slightly lower Lysholm score for the nonsurgically treated group. This difference was attributed to more instability symptoms. However, there were significantly more meniscus injuries in patients initially treated non-surgically with the status of the menisci being the most important 
Table 4. Summary of Timing of Surgery RCTs

\begin{tabular}{|c|c|c|c|c|c|}
\hline & RCT & $\begin{array}{l}\text { Level of } \\
\text { Evidence }\end{array}$ & Interventions & Outcome Measures & Results \\
\hline \multirow[t]{5}{*}{$\overline{\text { KANON trial }}$} & Frobell et al., $2010^{41}$ & I & $\begin{array}{l}\text { Structured rehabilitation } \\
\text { plus early ACLR vs } \\
\text { structured rehabilitation } \\
\text { with optional delayed } \\
\text { ACLR at } 2 \text { years' FU (n = } \\
\text { 121) }\end{array}$ & $\begin{array}{l}\text { KOOS, SF-36, Tegner } \\
\text { Scale. }\end{array}$ & $\begin{array}{l}\text { No statistically significant } \\
\text { differences between the } \\
2 \text { groups. }\end{array}$ \\
\hline & Frobell et al., $2013^{42}$ & & at 5 years' $\mathrm{FU}$ & $\begin{array}{l}\text { KOOS, SF-36, Tegner } \\
\text { activity scale, meniscal } \\
\text { surgery, and } \\
\text { radiographic } \\
\text { osteoarthritis }\end{array}$ & $\begin{array}{l}\text { No statistically significant } \\
\text { differences between the } \\
2 \text { groups. }\end{array}$ \\
\hline & Kiadaliri et al., $2016^{43}$ & & $\begin{array}{l}\text { Economic evaluation at } 5 \\
\text { years }\end{array}$ & Cost-effectiveness QALYs & $\begin{array}{l}\text { No significant differences } \\
\text { between the groups. }\end{array}$ \\
\hline & Flosadottir et al., $2018^{48}$ & & at 6 years' FU & Knee Self-Efficacy Scale & $\begin{array}{l}\text { No significant differences } \\
\text { between the groups }\end{array}$ \\
\hline & Culvenor et al., $2019^{44}$ & & $\begin{array}{l}\text { Secondary analysis at } 5 \\
\text { years' FU }\end{array}$ & $\begin{array}{l}\text { PFJ cartilage loss MRI } \\
\text { based }\end{array}$ & $\begin{array}{l}\text { Early ACLR group had } \\
\text { significantly greater los } \\
\text { of patellar cartilage } \\
\text { thickness compared wit } \\
\text { optional delayed ACLR. }\end{array}$ \\
\hline \multirow[t]{3}{*}{ Same trial } & $\begin{array}{l}\text { Eriksson et al., } \\
2018^{45}\end{array}$ & II & $\begin{array}{l}\text { ACLR within } 8 \text { days of } \\
\text { injury vs delayed after } \\
\text { normalized ROM 6-10 } \\
\text { weeks after injury at } 6 \\
\text { months' FU }(\mathrm{n}=70)\end{array}$ & $\begin{array}{l}\text { Visual analog scale, ROM, } \\
\text { IKDC, Stability }\end{array}$ & $\begin{array}{l}\text { No significant differences } \\
\text { between the } 2 \text { groups, } \\
\text { although less muscle } \\
\text { atrophy in the early } \\
\text { group compared with } \\
\text { their contralateral side. }\end{array}$ \\
\hline & Von Essen et al., $2020^{46}$ & & At 1-year FU & $\begin{array}{l}\text { IKDC, stability, number of } \\
\text { sick-leave days }\end{array}$ & $\begin{array}{l}\text { No significant differences } \\
\text { between the groups in } \\
\text { clinical outcomes, } \\
\text { significantly more sick } \\
\text { days taken in the } \\
\text { delayed group. }\end{array}$ \\
\hline & Von Essen et al., $2020^{47}$ & & At 2 years' $\mathrm{FU}$ & $\begin{array}{l}\text { IKDC, KOOS, and manual } \\
\text { stability measurements }\end{array}$ & $\begin{array}{l}\text { No significant differences } \\
\text { between the groups. }\end{array}$ \\
\hline \multicolumn{2}{|c|}{ Bottoni et al.,2008 ${ }^{49}$} & I & $\begin{array}{l}\text { Early }(<21 \text { days }) \text { vs } \\
\text { delayed }(>6 \text { weeks }) \\
\text { hamstring autograft } \\
\text { ACLR at 1-year FU }(n= \\
69 \text { ) }\end{array}$ & $\begin{array}{l}\text { KT-1000, SANE, Lysholm, } \\
\text { and Tegner Activity } \\
\text { Score }\end{array}$ & $\begin{array}{l}\text { No statistically significant } \\
\text { differences between the } \\
\text { groups. }\end{array}$ \\
\hline \multicolumn{2}{|c|}{ Chen et al., $2015^{50}$} & II & $\begin{array}{l}\text { Acute (3-7 weeks) vs } \\
\text { chronic (6-11 months) } \\
\text { ACLR using ligament } \\
\text { advanced reinforcement } \\
\text { system (LARS) artificial } \\
\text { ligament in young adults } \\
(\mathrm{n}=55)\end{array}$ & $\begin{array}{l}\text { Lysholm scale, Tegner } \\
\text { rating, a KT-1000, IKDC, } \\
\text { Isokinetic strength } \\
\text { quadriceps and } \\
\text { hamstring }\end{array}$ & $\begin{array}{c}\text { No significant differences } \\
\text { between the groups. }\end{array}$ \\
\hline \multicolumn{2}{|c|}{ Manandhar et al., $2018^{51}$} & II & $\begin{array}{l}\text { Early ( } 3 \text { weeks) vs delayed } \\
\text { (6 weeks) ACLR }(\mathrm{n}= \\
104)\end{array}$ & $\begin{array}{l}\text { ROM, IKDC and Tegner } \\
\text { scores }\end{array}$ & $\begin{array}{l}\text { No significant differences } \\
\text { between the groups }\end{array}$ \\
\hline
\end{tabular}

ACLR, anterior cruciate ligament reconstruction; FU, follow-up; IKDC, International Knee Documentation Committee; KOOS, Knee Injury and Osteoarthritis Outcome Score; MRI, magnetic resonance imaging; PFJ, patellofemoral joint; QALYs, quality-adjusted life years; ROM, range of motion; SANE, Single Assessment Numerical Evaluation; SF-36, Short Form-36.

predictor of developing arthritic changes. Further, onethird of the nonsurgically treated patients later required ACLR for instability.

\section{Long-Term Follow Up RCTs ( $\geq 10$ Years)}

The vast majority of RCTs have only reported shortto medium-term follow-up. Fourteen RCTs $(4.7 \%)$ have reported long-term outcomes beyond 10 years' follow-up; some have been listed in previous relevant group interventions. Some of the important long-term findings include greater allograft failures compared with autografts ${ }^{21}$ and high incidence of osteoarthritic changes in reconstructed knees ranging from $22 \%$ to $100 \% .^{60-65}$ There were no significant differences in 
Table 5. Long-Term Follow-Up RCTs

\begin{tabular}{|c|c|c|c|c|c|}
\hline RCT & $\begin{array}{l}\text { Level of } \\
\text { Evidence }\end{array}$ & Subgroup & Interventions & Outcome measures & Results \\
\hline Bottoni et al., $2015^{21}$ & $\mathrm{I}$ & Allograft & $\begin{array}{l}\text { Hamstring autograft vs } \\
\text { tibialis posterior allograft } \\
\text { at minimum } 10 \text { years } \\
(\mathrm{n}=96 / 99)\end{array}$ & $\begin{array}{l}\text { Graft failure, subjective } \\
\text { knee stability and } \\
\text { functional status SANE, } \\
\text { Tegner, and IKDC scores. }\end{array}$ & $\begin{array}{l}4(8.3 \%) \text { autograft vs } 13 \\
(26.5 \%) \text { allograft failures } \\
\text { required revision. In } \\
\text { remaining patients } \\
\text { whose graft was intact, } \\
\text { there was no difference } \\
\text { in functional scores. }\end{array}$ \\
\hline Sundaraj et al., $2020^{66}$ & I & Biofixation & $\begin{array}{l}\text { Bioabsorbable vs titanium } \\
\text { screws (hamstring } \\
\text { autograft) at } 13 \text { years } \\
(\mathrm{n}=40)\end{array}$ & $\begin{array}{l}\text { IKDC, KT-1000, MRI- } \\
\text { tunnel volumes, } \\
\text { ossification around } \\
\text { screw, graft integration, } \\
\text { and cyst formation. }\end{array}$ & $\begin{array}{l}\text { No significant differences } \\
\text { between the groups. }\end{array}$ \\
\hline $\begin{array}{l}\text { Stensbirk et al., } \\
2014^{70}\end{array}$ & I & $\begin{array}{l}\text { Different } \\
\text { autografts }\end{array}$ & $\begin{array}{l}\text { Iliotibial band vs BPTB at } \\
15 \text { years }(\mathrm{n}=49 / 60)\end{array}$ & $\begin{array}{l}\text { Failure rate, KOOS, } \\
\text { Tegner, anterior knee } \\
\text { pain, Lysholm score, } \\
\text { Rolimeter laxity, } \\
\text { extension deficit. }\end{array}$ & $\begin{array}{l}\text { No significant differences } \\
\text { between the groups. }\end{array}$ \\
\hline Castoldi et al., $2020^{60}$ & II & EAT & $\begin{array}{l}\text { BPTB }+/- \text { lateral extra- } \\
\text { articular tenodesis at } \\
19.4 \text { years }(\mathrm{n}=79 / 121)\end{array}$ & $\begin{array}{l}\text { Clinical outcomes, IKDC, } \\
\text { radiographs }\end{array}$ & $\begin{array}{l}\text { No significant differences } \\
\text { between the groups } \\
\text { although more lateral } \\
\text { OA in EAT group }(59 \% \\
\text { vs } 22 \% ; P=.02 ; \mathrm{n}=45 \text { / } \\
\text { 121). }\end{array}$ \\
\hline $\begin{array}{l}\text { Meunier et al., } \\
2007^{59}\end{array}$ & II & Others & $\begin{array}{l}\text { Operative vs non-op at } 15 \\
\text { years' FU }(n=100)\end{array}$ & KOOS, Lysholm, OA & $\begin{array}{l}\text { No significant differences } \\
\text { between the groups, } \\
\text { ACLR neither reduced } \\
\text { risk of OA nor increased } \\
\text { subjective outcome } \\
\text { scores. However, there } \\
\text { were significantly more } \\
\text { meniscus injuries in } \\
\text { patients initially treated } \\
\text { nonoperatively; 1/3 } \\
\text { nonoperative patients } \\
\text { later had ACLR for } \\
\text { instability. }\end{array}$ \\
\hline Holm et al., $2012^{61}$ & II & Others & $\begin{array}{l}\text { Open vs arthroscopic at } 12 \\
\text { years }(\mathrm{n}=53 / 67)\end{array}$ & $\begin{array}{l}\text { Prevalence of OA on } \\
\text { radiographs, Cincinnati } \\
\text { score, clinical } \\
\text { assessments }\end{array}$ & $\begin{array}{l}\text { No significant differences } \\
\text { between the groups (OA: } \\
79 \% \text { vs } 80 \% \text { ) }\end{array}$ \\
\hline Sajovic et al., $2018^{62}$ & II & $\begin{array}{l}\text { Patella vs } \\
\text { hamstrings }\end{array}$ & $\begin{array}{l}\text { Patellar vs hamstring } \\
\text { autografts at } 17 \text { years } \\
(\mathrm{n}=48 / 64)\end{array}$ & $\begin{array}{l}\text { IKDC, KT-1000 } \\
\text { arthrometer, and } \\
\text { radiography, SF -36, } \\
\text { graft failure }\end{array}$ & $\begin{array}{l}\text { No significant differences } \\
\text { between the groups } \\
\text { although more OA with } \\
\text { patella }(100 \% \text { vs } 71 \% ; \\
(P=.004)\end{array}$ \\
\hline Björnsson et al., $2016^{67}$ & II & $\begin{array}{l}\text { Patella vs } \\
\text { hamstrings }\end{array}$ & $\begin{array}{l}\text { Patellar vs hamstrings } \\
\text { autografts at } 16 \text { years } \\
(\mathrm{n}=147 / 193)\end{array}$ & $\begin{array}{l}\text { Laxity measurements, } \\
\text { functional outcomes, } \\
\text { PROMS, bilateral } \\
\text { standing radiographs }\end{array}$ & $\begin{array}{l}\text { No significant differences } \\
\text { between the groups, } \\
\text { significantly more signs } \\
\text { of OA in the } \\
\text { reconstructed knee vs } \\
\text { contralateral knee. }\end{array}$ \\
\hline Webster et al., $2016^{69}$ & I & $\begin{array}{l}\text { Patella vs } \\
\text { hamstrings }\end{array}$ & $\begin{array}{l}\text { Patellar vs hamstrings at } \\
15.3 \text { years }(\mathrm{n}=47 / 65)\end{array}$ & $\begin{array}{l}\text { Clinical assessment, } \\
\text { anterior pain, laxity, } \\
\text { ROM, radiographic } \\
\text { outcomes }\end{array}$ & $\begin{array}{l}\text { No significant difference } \\
\text { between the groups. }\end{array}$ \\
\hline Barenius et al., $2014^{63}$ & I & $\begin{array}{l}\text { Patella vs } \\
\text { hamstrings }\end{array}$ & $\begin{array}{l}\text { Patella vs hamstrings at } 14 \\
\text { years }(\mathrm{n}=135 / 164)\end{array}$ & $\begin{array}{l}\text { Radiological examination, } \\
\text { Tegner, KOOS }\end{array}$ & $\begin{array}{l}\text { No significant difference } \\
\text { between the groups. (OA } \\
49 \% \text { vs } 65 \% ; P=.073 \text { ). }\end{array}$ \\
\hline
\end{tabular}


Table 5. Continued

\begin{tabular}{|c|c|c|c|c|c|}
\hline RCT & $\begin{array}{l}\text { Level of } \\
\text { Evidence }\end{array}$ & Subgroup & Interventions & Outcome measures & Results \\
\hline Konrads et al., $2016^{68}$ & II & $\begin{array}{l}\text { Patella vs } \\
\text { hamstrings }\end{array}$ & $\begin{array}{l}\text { Patella vs hamstrings at } 10 \\
\text { years }(\mathrm{n}=47 / 62)\end{array}$ & $\begin{array}{l}\text { KT-1000, VAS, IKDC, } \\
\text { Lysholm score, Tegner } \\
\text { scale, and standard } \\
\text { radiographs }\end{array}$ & $\begin{array}{c}\text { No significant difference } \\
\text { between the groups. }\end{array}$ \\
\hline Sporsheim et al., $2019^{64}$ & I & Repair & $\begin{array}{l}\text { Open repair methods: } \\
\text { acute primary repair, } \\
\text { acute repair with a } \\
\text { ligament augmentation } \\
\text { device or BPTB ACLR at } \\
30 \text { years }(\mathrm{n}=113 / 150)\end{array}$ & $\begin{array}{l}\text { Tegner and Lysholm } \\
\text { questionnaires, } \\
\text { radiographic } \\
\text { examination, revisions } \\
\text { and knee arthroplasties. }\end{array}$ & $\begin{array}{l}\text { Prevalence of OA } 42 \%, \\
\text { BPTB had significantly } \\
\text { less rate of revision. No } \\
\text { significant differences } \\
\text { between the groups } \\
\text { (remaining patients) }\end{array}$ \\
\hline $\begin{array}{l}\text { Järvelä et al., } \\
2017^{65}\end{array}$ & II & $\begin{array}{l}\text { Single- vs } \\
\text { double- } \\
\text { bundle }\end{array}$ & $\begin{array}{l}\text { Single- (bio-screw) vs } \\
\text { single- (metal-screw) vs } \\
\text { double-bundle } \\
\text { (bioscrew) at } 10 \text { years' } \\
\text { FU }(\mathrm{n}=81 / 90)\end{array}$ & $\begin{array}{l}\text { KT-1000, IKDC, Lysholm } \\
\text { scores, radiographic } \\
\text { examination }\end{array}$ & $\begin{array}{l}\text { Revision: } 1 \text { DB vs } 7 \text { SB-Bio } \\
\text { vs } 3 \text { SB-metal }(P=.043) \text {. } \\
\text { No significant differences } \\
\text { between the groups in } \\
\text { clinical outcomes or OA } \\
\text { ( } 38 \% \text { vs } 28 \% \\
\text { contralateral knee). }\end{array}$ \\
\hline Annear et al., $2019^{71}$ & II & Technique & $\begin{array}{l}\text { Remnant ACL preservation } \\
\text { vs debridement graft } \\
\text { hamstring autograft at } \\
10 \text { years }(\mathrm{n}=44 / 49)\end{array}$ & $\begin{array}{l}\text { Graft failure rates, } \\
\text { subjective outcomes }\end{array}$ & $\begin{array}{l}\text { No significant differences } \\
\text { between the groups. }\end{array}$ \\
\hline Drogset et al., $2006^{40}$ & II & Technique & $\begin{array}{l}\text { Acute primary repair, acute } \\
\text { repair augmented with a } \\
\text { synthetic ligament- } \\
\text { augmentation device or } \\
\text { acute repair with } \\
\text { autologous BPTB graft at } \\
16 \text { years }(\mathrm{n}=129 / 147)\end{array}$ & $\begin{array}{l}\text { Tegner activity score and } \\
\text { Lysholm functional } \\
\text { score. Stability (clinical } \\
\text { examination and KT- } \\
1000 \text { arthrometer). }\end{array}$ & $\begin{array}{l}\text { Revision rate: } 24 \%, 10 \% \text {, } \\
\text { and } 2 \% \text { respectively. The } \\
\text { rate of revision was } 10 \\
\text { times greater in the } \\
\text { group that had primary } \\
\text { repair than in the group } \\
\text { that had repair with } \\
\text { BPTB ( } P=.003 \text { ) and the } \\
\text { latter had significantly } \\
\text { better stability } \\
\text { (Lachman). OA changes } \\
\text { noted in } 11 \% \text { in the } \\
\text { reconstructed knee vs } \\
3.5 \% \text { in the contralateral } \\
\text { knee }(P=.001) \text {; no } \\
\text { differences between } \\
\text { groups. }\end{array}$ \\
\hline
\end{tabular}

ACL, anterior cruciate ligament; ACLR, anterior cruciate ligament reconstruction; BPTB, bone-patella tendon-bone; DB, double bundle; FU, follow-up; IKDC, International Knee Documentation Committee; KOOS, Knee Injury and Osteoarthritis Outcome Score; MRI, magnetic resonance imaging; OA, osteoarthritis; PROM, patient-reported outcome measures; RCT, randomized controlled trial; ROM, range of motion; SANE, Single Assessment Numerical Evaluation; SB, single bundle; SF-36, Short Form-36; VAS, visual analog scale.

outcomes reported between bioabsorbable or metal screws for graft fixation, ${ }^{66}$ patellar versus hamstrings, ${ }^{62,63,67-69}$ open versus arthroscopic, ${ }^{61}$ or singleversus double-bundle reconstructions ${ }^{65}$ (Table 5). ${ }^{21,40,59-71}$

\section{Discussion}

The most important finding is that only $10 \%$ of trials reported any significant differences between the intervention and the control groups for the outcome measures used by those trials. While debates continue on choice of grafts, single- or double-bundle reconstruction, tunnel placements, and fixation techniques through to the use of navigation technology, a number of conclusions can be drawn from this study. For the vast majority of patients, using standard arthroscopic techniques, a single- or double-bundle ACLR with hamstrings/patella autografts, with transportal technique, and graft fixation techniques familiar to the surgeon achieve satisfactory clinical outcomes as reported by the included RCTs.

Timing of surgery is an important consideration for surgeons and patients alike and, overall, the RCT evidence showed that delayed surgery did not compromise outcome. More than one third of trials (101/299) looked at different graft choices for ACLR from the most commonly used autografts to synthetic ligaments with only 8 RCTs $(7.9 \%)$ reporting significant differences. This demonstrates a lack of clinical superiority of any one graft type over another; each has its own 
advantages and disadvantages that should be taken into consideration. Similarly, single- versus double-bundle reconstruction has been examined by 42 RCTs and comparable outcomes are demonstrated in all but 2 RCTs. Another 48 RCTs compared graft fixation techniques with no reported significant differences between bioabsorbable and metal screws or the use of suspensory fixation techniques, cross-pin fixation, or interference screws. Other more recent and contemporary techniques also did not show any significant differences using navigation technology or PRP. Finally, almost 50 RCTs studied variations of standard techniques or perioperative interventions, of which only $16 \%$ reported some measurable differences at short-term but no long-term influence on patients' outcomes. The majority of RCTs on ACLR have reported short- to medium-term follow-up. Only $4.7 \%$ included trials reported beyond 10 years outcomes. These trials provide valuable data on the sequalae of ACLR particularly on the development of degenerative changes.

In recent years, a number of systematic reviews and meta-analyses have evaluated different aspects of ACLR surgery as well as instructional reviews ${ }^{72}$ and practice guidelines. ${ }^{73}$ In their review of graft options, Mo et al. ${ }^{74}$ evaluated 45 RCTs and found that patellar tendon autograft was most appropriate in terms of IKDC and Lachman test results. Wang et al. ${ }^{75}$ evaluated 11 RCTs comparing clinical outcomes and adverse events associated with irradiated and nonirradiated allografts in ACLR and found no significant differences between autograft and nonirradiated allograft, although autograft offered greater advantages in functional outcomes and adverse events. Zeng et al. ${ }^{12}$ also compared autograft with allograft ACLR across 9 RCTs and 10 systematic reviews and found that autografts had greater advantages than irradiated allografts with respect to function and stability, whereas there were no significant differences between autografts and nonirradiated allografts. In their review of 8 RCTs, Belk et al ${ }^{14}$ found that BPTB or hamstring autograft had a similar incidence of postoperative knee OA at long-term followup. Similarly, Chee et al. in their review of 19 RCTs comparing contemporary 4-strand hamstrings with patellar tendon autografts found comparable results in clinical stability and postoperative functional status across most parameters studied. Although, hamstrings autografts carried lower risk of postoperative complications such as anterior knee pain, kneeling discomfort, and extension deficit. ${ }^{13}$

\section{Limitations}

This study is not without limitations. We did not calculate the treatment effect of individual trials with significant statistical findings and whether this correlated with clinically measurable effects. Further, the quality of those RCTs or of reporting was not addressed as this aspect falls outside the scope of this study. Although debate may continue on certain variations of ACLR surgery, sufficient RCT evidence is available for some points of contention such as timing of surgery, choice of graft, graft fixation techniques and navigation. However, there is a need in the published literature for further long-term studies of high-quality RCTs particularly existing ones.

\section{Conclusions}

The evidence indicates that a standard arthroscopic single- or double-bundle ACLR with hamstrings/patella autografts, transportal technique, and fixation techniques familiar to the surgeon leads to comparable results. This evidence offers surgeons the flexibility to use standard and cost-effective techniques and achieve comparable outcomes.

\section{References}

1. Mall NA, Chalmers PN, Moric M, et al. Incidence and trends of anterior cruciate ligament reconstruction in the United States. Am J Sports Med 2014;42:2363-2370.

2. Rayan F, Nanjayan SK, Quah C, Ramoutar D, Konan S, Haddad FS. Review of evolution of tunnel position in anterior cruciate ligament reconstruction. World J Orthop 2015;6:252-262.

3. Granan LP, Forssblad M, Lind M, Engebretsen L. The Scandinavian ACL registries 2004-2007: Baseline epidemiology. Acta Orthop 2009;80:563-567.

4. Prentice HA, Lind M, Mouton C, et al. Patient demographic and surgical characteristics in anterior cruciate ligament reconstruction: A description of registries from six countries. Br J Sports Med 2018;52:716-722.

5. Snook GA. A short history of the anterior cruciate ligament and the treatment of tears. Clin Orthop Relat Res 1983;172:11-13.

6. The classic. Operation for repair of the crucial ligaments Ernest W. Hey Groves, MD., F.R.C.S. Clin Orthop Relat Res 1980;147:4-6.

7. Svantesson E, Hamrin Senorski E, Webster KE, et al. Clinical outcomes after anterior cruciate ligament injury: Panther symposium ACL injury clinical outcomes consensus group. Knee Surg Sports Traumatol Arthrosc 2020;28:2415-2434.

8. Altman DG, Schulz KF, Moher D, et al. The revised CONSORT statement for reporting randomized trials: Explanation and elaboration. Ann Intern Med 2001;134: 663-694.

9. Evidence-Based-Medicine-Working-Group. Evidencebased medicine: A new approach to teaching the practice of medicine. JAMA 1992;268:2420-2425.

10. Prescott RJ, Counsell CE, Gillespie WJ, et al. Factors that limit the quality, number and progress of randomised controlled trials. Health Technol Assess 1999;3:1-143.

11. McCulloch P, Taylor I, Sasako M, Lovett B, Griffin D. Randomised trials in surgery: Problems and possible solutions. BMJ 2002;324:1448-1451.

12. Zeng C, Gao SG, Li H, et al. Autograft versus allograft in anterior cruciate ligament reconstruction: A meta-analysis 
of randomized controlled trials and systematic review of overlapping systematic reviews. Arthroscopy 2016;32: 153-163.el18.

13. Chee MY, Chen Y, Pearce CJ, et al. Outcome of patellar tendon versus 4-strand hamstring tendon autografts for anterior cruciate ligament reconstruction: A systematic review and meta-analysis of prospective randomized trials. Arthroscopy 2017;33:450-463.

14. Belk JW, Kraeutler MJ, Carver TJ, McCarty EC. Knee osteoarthritis after anterior cruciate ligament reconstruction with bone-patellar tendon-bone versus hamstring tendon autograft: A systematic review of randomized controlled trials. Arthroscopy 2018;34:1358-1365.

15. Anderson MJ, Browning WM 3rd, Urband CE, Kluczynski MA, Bisson LJ. A systematic summary of systematic reviews on the topic of the anterior cruciate ligament. Orthop J Sports Med 2016;4:2325967116634074.

16. Kay J, Memon M, Sa D, et al. A historical analysis of randomized controlled trials in anterior cruciate ligament surgery. J Bone Joint Surg Am 2017;99:2062-2068.

17. Moher D, Liberati A, Tetzlaff J, Altman DG. Preferred reporting items for systematic reviews and meta-analyses: The PRISMA statement. PLoS Med 2009;6:e1000097.

18. Lefebvre C, Manheimer E, Glanville J. Chapter 6: Searching for studies. In: Higgins JPT, Green S, eds. Cochrane Handbook for systematic reviews of interventions. Version 5.1.0. The Cochrane Collaboration, 2011 [updated March 2011]. www.handbook.cochrane.org

19. Tian S, Ha C, Wang B, et al. Arthroscopic anatomic double-bundle ACL reconstruction using irradiated versus non-irradiated hamstring tendon allograft. Knee Surg Sports Traumatol Arthrosc 2017;25:251-259.

20. Niu Y, Niu C, Wang X, et al. Improved ACL reconstruction outcome using double-layer BPTB allograft compared to that using four-strand hamstring tendon allograft. Knee 2016;23:1093-1097.

21. Bottoni CR, Smith EL, Shaha J, et al. Autograft versus allograft anterior cruciate ligament reconstruction: A prospective, randomized clinical study with a minimum 10-year follow-up. Am J Sports Med 2015;43:2501-2509.

22. Zhao J, He Y, Wang J. Double-bundle anterior cruciate ligament reconstruction: Four versus eight strands of hamstring tendon graft. Arthroscopy 2007;23:766-770.

23. Ferretti A, Vadalà A, De Carli A, Argento G, Conteduca F, Severini G. Minimizing internal rotation strength deficit after use of semitendinosus for anterior cruciate ligament reconstruction: A modified harvesting technique. Arthroscopy 2008;24:786-795.

24. Mohtadi NG, Chan DS. A randomized clinical trial comparing patellar tendon, hamstring tendon, and double-bundle acl reconstructions: Patient-reported and clinical outcomes at 5-year follow-up. J Bone Joint Surg Am 2019;101:949-960.

25. Zaffagnini S, Marcacci M, Lo Presti M, Giordano G, Iacono F, Neri MP. Prospective and randomized evaluation of ACL reconstruction with three techniques: A clinical and radiographic evaluation at 5 years follow-up. Knee Surg Sports Traumatol Arthrosc 2006;14:1060-1069.

26. Dahlstedt L, Dalén N, Jonsson U. Goretex prosthetic ligament vs Kennedy ligament augmentation device in anterior cruciate ligament reconstruction. A prospective randomized 3-year follow-up of 41 cases. Acta Orthop Scand 1990;61:217-224.

27. Takeda Y, Iwame T, Takasago T, et al. Comparison of tunnel orientation between transtibial and anteromedial portal techniques for anatomic double-bundle anterior cruciate ligament reconstruction using 3-dimensional computed tomography. Arthroscopy 2013;29:195-204.

28. Venosa M, Delcogliano M, Padua R, Alviti F, Delcogliano A. Femoral tunnel positioning in anterior cruciate ligament reconstruction: Anteromedial portal versus transtibial technique-a randomized clinical trial. Joints 2017; 5:34-38.

29. Mirzatolooei F. Comparison of short term clinical outcomes between transtibial and transportal TransFix ${ }^{\circledR}$ femoral fixation in hamstring ACL reconstruction. Acta Orthop Traumatol Turc 2012;46:361-366.

30. Kim JG, Chang MH, Lim HC, Bae JH, Ahn JH, Wang JH. Computed tomography analysis of the femoral tunnel position and aperture shape of transportal and outside-in ACL reconstruction: Do different anatomic reconstruction techniques create similar femoral tunnels? Am J Sports Med 2013;41:2512-2520.

31. Nakamura K, Nakamura T, Horie M, et al. Anatomic femoral tunnel placement is difficult by the transtibial technique: Comparison of three different femoral tunnel drilling techniques in double-bundle anterior cruciate ligament reconstructions. Knee Surg Sports Traumatol Arthrosc 2020;28:584-593.

32. Getgood AMJ, Bryant DM, Litchfield R, et al. Lateral extra-articular tenodesis reduces failure of hamstring tendon autograft anterior cruciate ligament reconstruction: 2-year outcomes from the STABILITY study randomized clinical trial. Am J Sports Med 2020;48: 285-297.

33. Porter M, Shadbolt B. Modified iliotibial band tenodesis is indicated to correct intraoperative residual pivot shift after anterior cruciate ligament reconstruction using an autologous hamstring tendon graft: A prospective randomized controlled trial. Am J Sports Med 2020;48:1069-1077.

34. Hamido F, Habiba AA, Marwan Y, et al. Anterolateral ligament reconstruction improves the clinical and functional outcomes of anterior cruciate ligament reconstruction in athletes. Knee Surg Sports Traumatol Arthrosc 2021;29:1173-1180.

35. Siebold R, Dehler C, Ellert T. Prospective randomized comparison of double-bundle versus single-bundle anterior cruciate ligament reconstruction. Arthroscopy 2008;24: $137-145$.

36. Zaffagnini S, Bruni D, Marcheggiani Muccioli GM, et al. Single-bundle patellar tendon versus non-anatomical double-bundle hamstrings ACL reconstruction: A prospective randomized study at 8-year minimum follow-up. Knee Surg Sports Traumatol Arthrosc 201 1;19:390-397.

37. Yasuda K, Tsujino J, Tanabe Y, Kaneda K. Effects of initial graft tension on clinical outcome after anterior cruciate ligament reconstruction. Autogenous doubled hamstring tendons connected in series with polyester tapes. Am J Sports Med 1997;25:99-106.

38. Khare R, Lal H, Vidyarthi K, Jangira V, Mittal D. Randomised comparison of pretensioning using cyclical loading and on tendon board for arthroscopic anterior cruciate 
ligament reconstruction using hamstring autograft. J Clin Orthop Trauma 2017;8:259-264.

39. DeFroda SF, Karamchedu NP, Budacki R, et al. Evaluation of graft tensioning effects in anterior cruciate ligament reconstruction between hamstring and bone-patellar tendon bone autografts [published online January 21, 2020]. J Knee Surg. https://doi.org/10.1055/s-00393402046.

40. Drogset JO, Grøntvedt T, Robak OR, Mølster A, Viset AT, Engebretsen L. A sixteen-year follow-up of three operative techniques for the treatment of acute ruptures of the anterior cruciate ligament. J Bone Joint Surg Am 2006;88:944-952.

41. Frobell RB, Roos EM, Roos HP, Ranstam J, Lohmander LS. A randomized trial of treatment for acute anterior cruciate ligament tears. $N$ Engl J Med 2010;363: $331-342$.

42. Frobell RB, Roos HP, Roos EM, Roemer FW, Ranstam J, Lohmander LS. Treatment for acute anterior cruciate ligament tear: Five year outcome of randomised trial. BMJ 2013;346:1232.

43. Kiadaliri AA, Englund M, Lohmander LS, Carlsson KS, Frobell RB. No economic benefit of early knee reconstruction over optional delayed reconstruction for ACL tears: Registry enriched randomised controlled trial data. Br J Sports Med 2016;50:558-563.

44. Culvenor AG, Eckstein F, Wirth W, Lohmander LS, Frobell R. Loss of patellofemoral cartilage thickness over 5 years following ACL injury depends on the initial treatment strategy: results from the KANON trial. $\mathrm{Br} J$ Sports Med 2019;53:1168-1173.

45. Eriksson K, von Essen C, Jönhagen S, Barenius B. No risk of arthrofibrosis after acute anterior cruciate ligament reconstruction. Knee Surg Sports Traumatol Arthrosc 2018;26:2875-2882.

46. von Essen C, McCallum S, Barenius B, Eriksson K. Acute reconstruction results in less sick-leave days and as such fewer indirect costs to the individual and society compared to delayed reconstruction for ACL injuries. Knee Surg Sports Traumatol Arthrosc 2020;28:2044-2052.

47. von Essen C, Eriksson K, Barenius B. Acute ACL reconstruction shows superior clinical results and can be performed safely without an increased risk of developing arthrofibrosis. Knee Surg Sports Traumatol Arthrosc 2020;28: 2036-2043.

48. Flosadottir V, Frobell R, Roos EM, Ageberg E. Impact of treatment strategy and physical performance on future knee-related self-efficacy in individuals with ACL injury. BMC Musculoskelet Disord 2018;19:50.

49. Bottoni CR, Liddell TR, Trainor TJ, Freccero DM, Lindell KK. Postoperative range of motion following anterior cruciate ligament reconstruction using autograft hamstrings: A prospective, randomized clinical trial of early versus delayed reconstructions. Am J Sports Med 2008;36:656-662.

50. Chen J, Gu A, Jiang H, Zhang W, Yu X. A comparison of acute and chronic anterior cruciate ligament reconstruction using LARS artificial ligaments: A randomized prospective study with a 5-year follow-up. Arch Orthop Trauma Surg 2015;135:95-102.

51. Manandhar RR, Chandrashekhar K, Kumaraswamy V, Sahanand S, Rajan D. Functional outcome of an early anterior cruciate ligament reconstruction in comparison to delayed: Are we waiting in vain? J Clin Orthop Trauma 2018;9:163-166.

52. Jepsen CF, Lundberg-Jensen AK, Faunoe P. Does the position of the femoral tunnel affect the laxity or clinical outcome of the anterior cruciate ligament-reconstructed knee? A clinical, prospective, randomized, double-blind study. Arthroscopy 2007;23:1326-1333.

53. Mutsuzaki H, Kinugasa T, Ikeda K, Sakane M. Calcium phosphate-hybridized tendon grafts reduce femoral bone tunnel enlargement in anatomic single-bundle ACL reconstruction. Knee Surg Sports Traumatol Arthrosc 2018;26:500-507.

54. Funchal LFZ, Astur DC, Ortiz R, Cohen M. The presence of the arthroscopic "floating meniscus" sign as an indicator for surgical intervention in patients with combined anterior cruciate ligament and grade II medial collateral ligament injury. Arthroscopy 2019;35:930-937.

55. Vogrin M, Rupreht M, Dinevski D, et al. Effects of a platelet gel on early graft revascularization after anterior cruciate ligament reconstruction: A prospective, randomized, double-blind, clinical trial. Eur Surg Res 2010;45: 77-85.

56. Reda W, ElGuindy AMF, Zahry G, Faggal MS, Karim MA. Anterior cruciate ligament reconstruction; is a tourniquet necessary? A randomized controlled trial. Knee Surg Sports Traumatol Arthrosc 2016;24:2948-2952.

57. Cameron SE, Wilson W, St Pierre P. A prospective, randomized comparison of open vs arthroscopically assisted ACL reconstruction. Orthopedics 1995;18:249-252.

58. Krywulak SA, Mohtadi NG, Russell ML, Sasyniuk TM. Patient satisfaction with inpatient versus outpatient reconstruction of the anterior cruciate ligament: A randomized clinical trial. Can J Surg 2005;48:201-206.

59. Meunier A, Odensten M, Good L. Long-term results after primary repair or non-surgical treatment of anterior cruciate ligament rupture: a randomized study with a 15-year follow-up. Scand J Med Sci Sports 2007;17:230-237.

60. Castoldi M, Magnussen RA, Gunst S, et al. A Randomized controlled trial of bone-patellar tendon-bone anterior cruciate ligament reconstruction with and without lateral extra-articular tenodesis: 19-year clinical and radiological follow-up. Am J Sports Med 2020;48:1665-1672.

61. Holm I, Oiestad BE, Risberg MA, Gunderson R, Aune AK. No differences in prevalence of osteoarthritis or function after open versus endoscopic technique for anterior cruciate ligament reconstruction: 12-year follow-up report of a randomized controlled trial. Am J Sports Med 2012;40: 2492-2498.

62. Sajovic M, Stropnik D, Skaza K. Long-term comparison of semitendinosus and gracilis tendon versus patellar tendon autografts for anterior cruciate ligament reconstruction: A 17-year follow-up of a randomized controlled trial. Am J Sports Med 2018;46:1800-1808.

63. Barenius B, Ponzer S, Shalabi A, Bujak R, Norlén L, Eriksson K. Increased risk of osteoarthritis after anterior cruciate ligament reconstruction: A 14-year follow-up study of a randomized controlled trial. Am J Sports Med 2014;42:1049-1057.

64. Sporsheim AN, Gifstad T, Lundemo TO, et al. Autologous BPTB ACL reconstruction results in lower failure rates 
than ACL repair with and without synthetic augmentation at 30 years of follow-up: A prospective randomized study. J Bone Joint Surg Am 2019;101:2074-2081.

65. Järvelä S, Kiekara T, Suomalainen P, Järvelä T. Doublebundle versus single-bundle anterior cruciate ligament reconstruction: A prospective randomized study with 10year results. Am J Sports Med 2017;45:2578-2585.

66. Sundaraj K, Salmon LJ, Heath EL, et al. Bioabsorbable versus titanium screws in anterior cruciate ligament reconstruction using hamstring autograft: A prospective, randomized controlled trial with 13-year follow-up. Am J Sports Med 2020;48:1316-1326.

67. Björnsson H, Samuelsson K, Sundemo D, et al. A randomized controlled trial with mean 16-year followup comparing hamstring and patellar tendon autografts in anterior cruciate ligament reconstruction. Am J Sports Med 2016;44:2304-2313.

68. Konrads C, Reppenhagen S, Plumhoff P, Hoberg M, Rudert M, Barthel T. No significant difference in clinical outcome and knee stability between patellar tendon and semitendinosus tendon in anterior cruciate ligament reconstruction. Arch Orthop Trauma Surg 2016;136:521-525.

69. Webster KE, Feller JA, Hartnett N, Leigh WB, Richmond AK. Comparison of patellar tendon and hamstring tendon anterior cruciate ligament reconstruction: A 15-year follow-up of a randomized controlled trial. Am J Sports Med 2016;44:83-90.
70. Stensbirk F, Thorborg K, Konradsen L, Jørgensen U, Hölmich P. Iliotibial band autograft versus bone-patellatendon-bone autograft, a possible alternative for ACL reconstruction: A 15-year prospective randomized controlled trial. Knee Surg Sports Traumatol Arthrosc 2014;22:2094-2101.

71. Annear PT, Rohr EJ, Hille DM, Gohil S, Ebert JR. No clinical difference in 10-year outcomes between standard and minimal graft debridement techniques in patients undergoing anterior cruciate ligament reconstruction using autologous hamstrings: A randomized controlled trial. Knee Surg Sports Traumatol Arthrosc 2019;27:516-523.

72. Paschos NK, Howell SM. Anterior cruciate ligament reconstruction: Principles of treatment. EFORT Open Rev 2016;1:398-408.

73. Shea KG, Carey JL, Richmond J, et al. The American Academy of Orthopaedic Surgeons evidence-based guideline on management of anterior cruciate ligament injuries. J Bone Joint Surg Am 2015;97:672-674.

74. Mo Z, Li D, Yang B, Tang S. Comparative efficacy of graft options in anterior cruciate ligament reconstruction: A systematic review and network meta-analysis. Arthrosc Sports Med Rehabil 2020;2:e645-e654.

75. Wang S, Zhang C, Cai Y, Lin X. Autograft or allograft? Irradiated or not? A contrast between autograft and allograft in anterior cruciate ligament reconstruction: A meta-analysis. Arthroscopy 2018;34:3258-3265. 


\section{Appendix Table 1. References to RCTs per category with no significant findings}

\begin{tabular}{|c|c|}
\hline Category & References to RCTs \\
\hline \multicolumn{2}{|l|}{ Grafts } \\
\hline Hamstrings & $\begin{array}{l}\text { Krishna 2020, Ibrahim 2005, Tashiro 2003, Gobbi 2005, Franz 2016, McRae 2013, Karimi-Mobarakeh } 2015, \\
\quad \text { Ruffilli 2016, Liu 2018, Gupta } 2017\end{array}$ \\
\hline Quads & Vilchez-Cavazos 2020, Martin-Alguacil 2018, Lind 2020, Sinding 2020, Lund 2014, Barie 2020 \\
\hline Different autografts & Mei 2016, Stensbirk 2014, Bi 2018 \\
\hline Synthetic & Muren 2003, Ghalayini 2010, Engstrom 1993, Drogset 2002, Elveos 2018, Peterson 2014 \\
\hline \multicolumn{2}{|r|}{ (1) } \\
\hline Biofixation & $\begin{array}{l}\text { Jagodzinski 2010, Hegde 2014, Capuano 2008, Buhren 200, Marks 2008, Arneja 2004, Sundaraj 2020, Arama } \\
\text { 2015, Fink 2000, Hackl 2000, Drogset 2011, Drogset 2006, Robert 2004, Stengel 2009, Moisala 2008, } \\
\text { Chiang 2019, Bourke 2013, Suomalainen 2012, Kaeding 2005, Roger 2020, Laxdal 2006, Noh 2012, Järvelä } \\
\text { 2008, Stener 2010, Carulli 2017, Myers 2008, Harilainen 2009, Benedetto 2000, McGuire } 1999\end{array}$ \\
\hline Femoral fixation & $\begin{array}{l}\text { Price 2010, Ibrahim 2015, Harilainen 2005, Björkman 2015, Sabat 2011, Mousavi 2017, da Silva Guarilha } \\
\text { 2012, Hill 2005, Harilainen 2006, Fauno 2005, Mayr 2017, Mayr 2020, Kouloumentas 2019, Sharifzadeh } \\
\text { 2017, DeWall 2011, Shumborski } 2019\end{array}$ \\
\hline Press-fit fixation & Geiges 2013, Hwang 2013, Sarzaeem 2014 \\
\hline \multicolumn{2}{|l|}{ Additional procedures } \\
\hline $\begin{array}{l}\text { Extra-articular tenodesis } \\
\text { ALLR }\end{array}$ & $\begin{array}{l}\text { Acquitter 2003, Anderson 2001, Trichine 2014, Castoldi 2020, Getgood 2020, McCormack } 2019 \\
\text { Ibrahim 2017, Sonnery-Cottet } 2020\end{array}$ \\
\hline Single vs double & $\begin{array}{l}\text { Kalawadia 2015, Debieux 2012, Araki 2011, Kanaya 2009, Beyaz 2017, Ikuta 2020, Beyaz 2012, Abdelrazek } \\
\text { 2019, Sastre 2010, Irrgang 2012, Bohn 2015, Núñez 2012, Koga 2015, Järvelä 2008, Taylor 2009, Xiang } \\
\text { 2019, Järvelä 2007, Adravanti 2017, Yang 2017, Mayr 2018, Mayr 2016, Wang 2009, Koken 2014, Liu } \\
\text { 2016, Muneta 2007, Aglietti 2010, Karikis 2016, Järvelä 2017, Zhang 2014, Zeman 2014, Ahldén 2013, } \\
\text { Sernert 2017, Song 2013, Aga 2018, Sasaki 2017, Suomalainen 2011, Hussein 2012, Zhang 2014, Lui 2012, } \\
\text { Streich 2008 }\end{array}$ \\
\hline ACL repair & Hoogeslag 2019, Schliemann 2018, Kösters 2020, Murray 2020, Sporsheim 2019 \\
\hline Techniques & $\begin{array}{l}\text { Petruskevicius 2002, Amendola 1999, Sørensen 2011, Matthews 2017, Demirag 2012, Silva 2014, Gohil 2007, } \\
\text { Annear 2019, Kosy 2020, Pujol 2012, Navali 2014, Lu 2015, Liu 2017, Koga 2015, Zhu 2018, Sharaby 2019, } \\
\text { Mutsuzaki 2018, Zhang 2018, McCormack 2006, Lubowitz 2013, Yazdi 2014, Ahn } 2019\end{array}$ \\
\hline Perioperative management & $\begin{array}{l}\text { Mendias 2020, Tobias 2020, Johnston 2020, Mahdi 2019, Zeman 2018, Walters 2018, Mirzatolooei } 2013 \text {, } \\
\text { Valentí Azcárate 2014, Lee 2020, Felli 2019, Chiang 2019, Arciero } \\
\text { 1996, Nicholas 2001, Nakayama } 2013\end{array}$ \\
\hline Others & McCarthy 1993, Maddison 2012, Curran 2020, Valkering 2015, Holm 2012, Raab 1993 \\
\hline
\end{tabular}

ACL, anterior cruciate ligament; ALLR, anterolateral ligament reconstruction; AM, anteromedial; OI, outside-in; RCT, randomized controlled trial; TP, transportal; TT, transtibial. 